\title{
The role of leptin in nutritional status and reproductive function
}

\author{
D. H. Keisler, J. A. Daniel and C. D. Morrison \\ Department of Animal Science, University of Missouri, Columbia, MO 65211, USA
}

\begin{abstract}
Infertility associated with suboptimal nutrition is a major concern among livestock producers. Undernourished prepubertal animals will not enter puberty until they are well fed; similarly, adult, normally cyclic females will stop cycling when faced with extreme undernutrition. Work in our laboratory has focused on how body fat (or adiposity) of an animal can communicate to the brain and regulate reproductive competence. In 1994, the discovery in rodents of the obese $(o b)$ gene product leptin, secreted as a hormone from adipocytes, provided a unique opportunity to understand and hence regulate whole body compositional changes. There is now evidence that similar mechanisms are functioning in livestock species in which food intake, body composition, and reproductive performance are of considerable economic importance. Leptin has been reported to be a potent regulator of food intake and reproduction in rodents. There is evidence indicating that at least some of the effects of leptin occur through receptor-mediated regulation of the hypothalamic protein neuropeptide $Y$ (NPY). NPY is a potent stimulator of food intake, is present at high concentrations in feed-restricted cattle and ewes, and is an inhibitor of LH secretion in these livestock species. In our investigations in sheep, we have cloned a partial cDNA corresponding to the ovine long-form leptin receptor, presumably the only fully active form, and have localized the long-form leptin receptor in the ventromedial and arcuate nuclei of the hypothalamus. Leptin receptor mRNA expression was colocalized with NPY mRNAcontaining cell bodies in those regions. We have also determined that hypothalamic leptin receptor expression is greater in feed-restricted ewes than in well-fed ewes. These observations provide a foundation for future investigations into the nutritional modulators of reproduction in livestock.
\end{abstract}

\section{Introduction}

The ancient sculpture known as Venus of Willendorf (Fig. 1) illustrates man's long known association between nutritional status and fertility. What is not known, however, is the mechanism by which the nutritional status of an animal regulates reproductive processes. In 1953, Kennedy acknowledged the association between nutrition and reproduction and proposed the 'lipostat' or 'setpoint' theory, which asserted that the reproductive performance of an animal was related positively to the animal's body-fat mass. Kennedy's work was followed by many studies which included the classical ventromedial hypothalamic (VMH) lesioning studies by Hervey (1958). Hervey concluded that VMH lesions ablated the satiety centre and resulted in mice that exhibited hyperphagia, obesity and infertility.

In addition, the parabiotic-mice trials of Coleman et al. (reviewed in 1978) were extraordinarily insightful. These researchers worked with two strains of obese mice, notably the ob/ob mice (identified as the first genetic anomaly of its kind; Ingalis et al., 1950), and the $d b / d b$ (or diabetic) mice. The consequence of parabiosing $o b / o b$ and $d b / d b$ mice with each other or with wild-type mice are illustrated in Fig 2. Mating of wild-type strains of mice with $o b / o b$ or $d b / d b$ mice resulted in offspring expressing simple Mendelian probabilities for the recessive traits. As a result of the lesioning and 


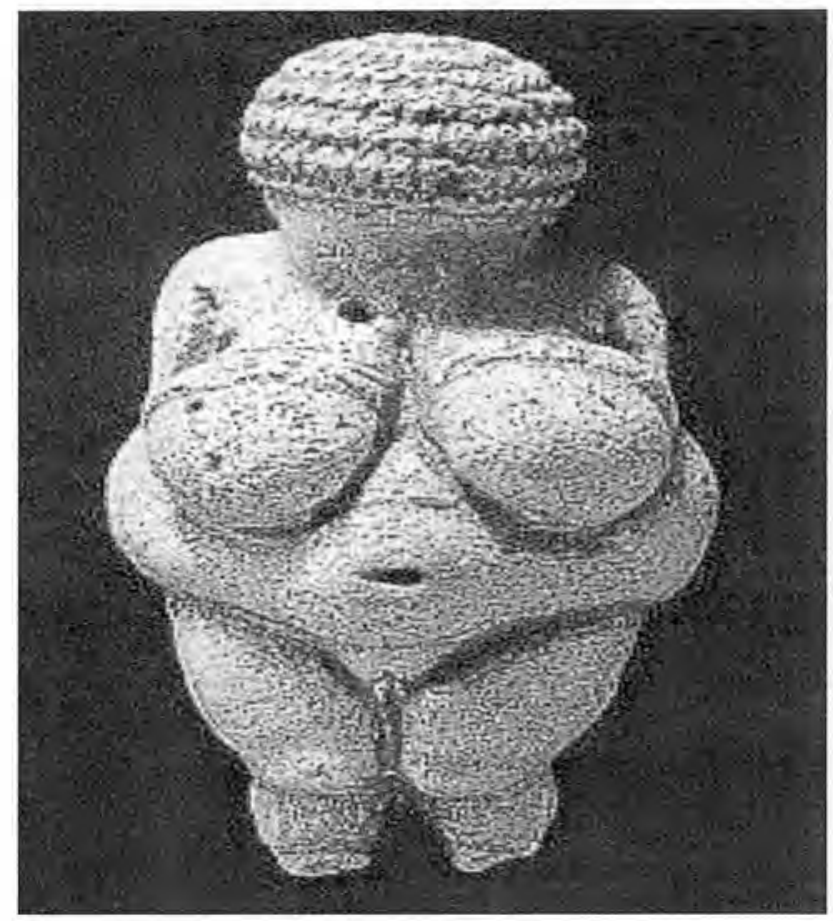

Fig. 1. Venus of Willendorf - a symbol of the Mother and Fertility Goddess. (ca. $\sim 25000$ years old).

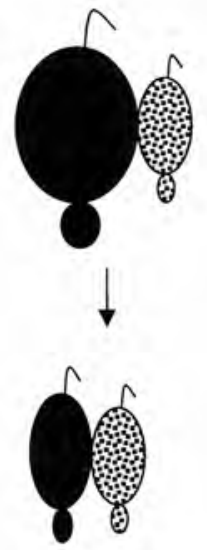

$o b+w t$
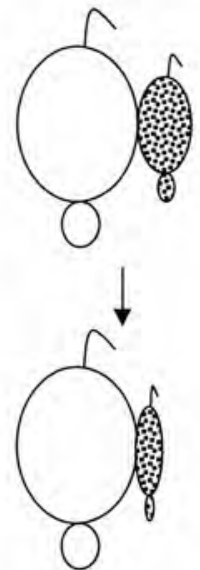

$d b+w t$

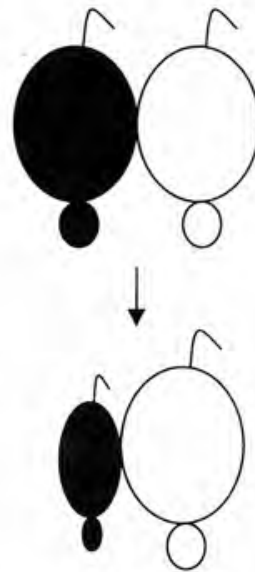

$o b+d b$

Fig. 2. Consequence of parabiosing $o b / o b$ and $d b / d b$ mice together or with wild-type mice. 


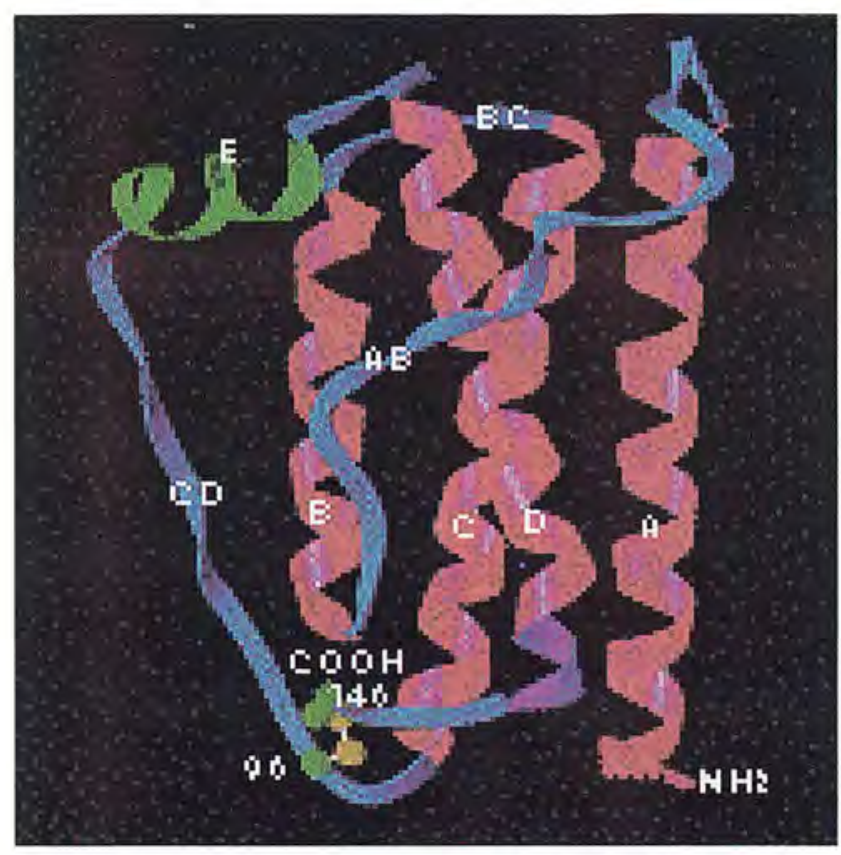

Fig. 3. Three-dimensional structural model of leptin.

parabiotic trials, it was concluded that blood-borne factors were responsible for communicating the animal's body composition to its brain. Elucidation (at least in part) of that 'body-to-brain' signal required more than two decades of additional work.

In 1994, Friedman and co-workers (Zhang et al., 1994) used positional cloning techniques to identify the 167 amino acid protein product of the $o b$ gene which was named leptin (derived from the Greek term 'leptos' meaning 'thin'). Subsequent nuclear magnetic resonance analysis of a crystalline form of leptin (E100; Zhang et al., 1997) revealed that it was present as a quadra-helical protein (Fig. 3). Structurally, leptin contains a single disulfide bond which links cysteines within the C and D helices and which has proven critical to the biological activity of leptin.

Originally, Friedman and colleagues (Zhang et al., 1994) reported that leptin was secreted exclusively by adipocytes; however, the list of tissues expressing leptin now includes the placental trophoblast, the mammary epithelium in primates and rodents, and avian liver. Unique to each of these tissues are their lipogenic-lipolytic capabilities. The importance of the lipogenic-lipolytic mechanisms in these tissues and particularly in the liver of oviparous and ovoviviparous animals (to include fish, birds, reptiles, select mammals (spp. Monotremata) and others), likely portends future reports of species-specific detection of leptin expression, particularly in liver or mammary epithelial tissue.

Concomitant with the identification of leptin, leptin receptors were cloned and are now known to occur in at least five variably spliced forms (OB-Ra-e; Li et al., 1998). The high structural similarity of leptin receptors to cytokine receptors has led to numerous reports referring to leptin as a member of the cytokine family. When leptin binds to its receptor, receptor dimerization occurs; this is also characteristic of members of the growth hormone-cytokine family of receptors (Devos et al., 1997; Girard, 1997; Liu et al., 1997; Nakashima et al., 1997). However, only one of the leptin receptors, referred to as $\mathrm{Ob}-\mathrm{Rb}$, or the 'long-form' of the leptin receptor is known to both span the cellular membrane and possess a 302 amino acid cytoplasmic domain. The G-protein-like signal transduction mechanism of the long-form of the leptin receptor is mediated most likely via 

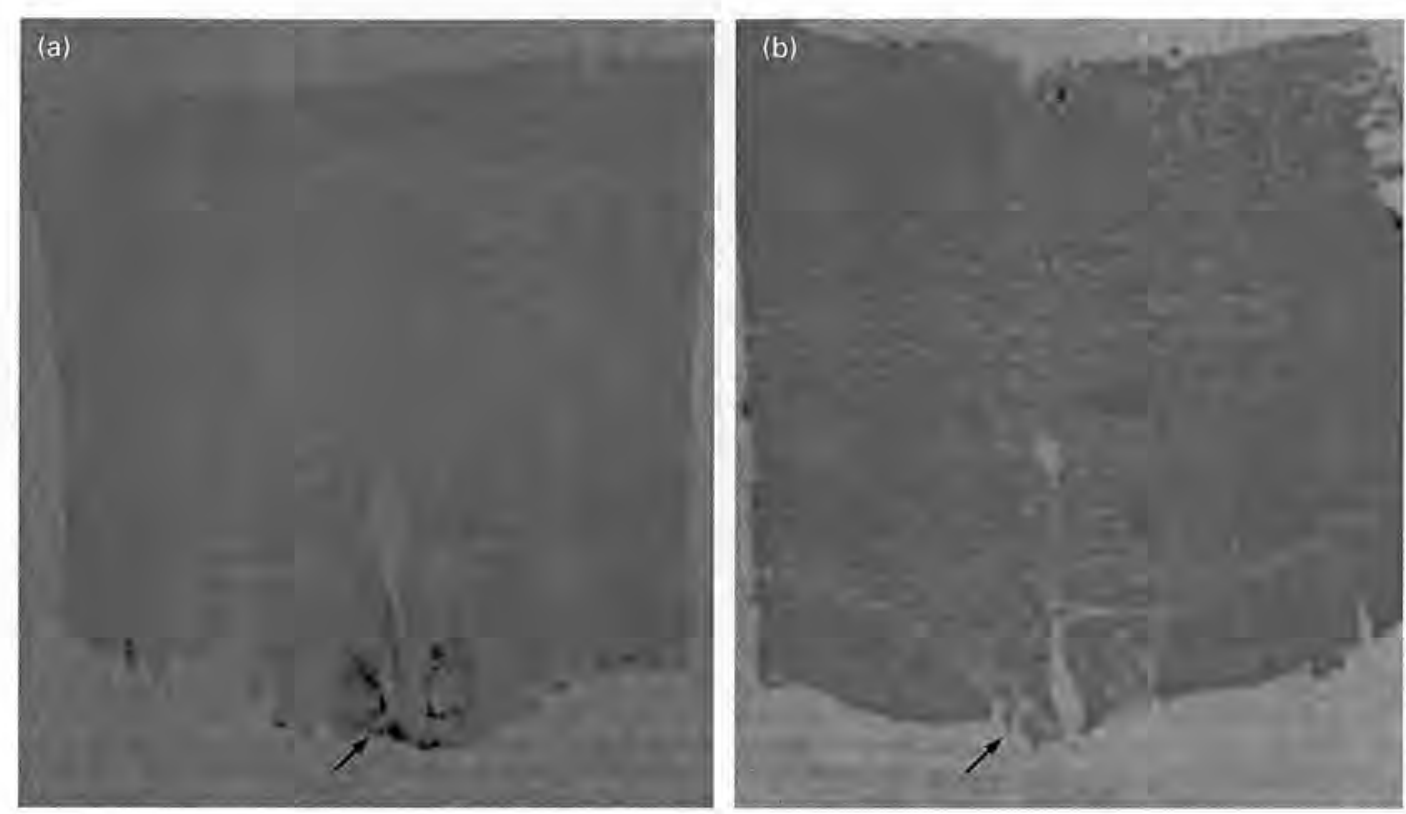

Fig. 4. Leptin receptor expression (arrow) in the ventromedial hypothalamus of feed-restricted (a) versus wellfed (b) ewes.

activation of janus kinase (JAK)-2/signal transducer and activator of transcription (STAT)-3, -5 or- 6 pathways (Bjorbaek et al., 1997). At least three of the short-forms of the leptin receptors $(\mathrm{Ob}-\mathrm{Ra}, \mathrm{c}$, and d) also possess cytoplasmic domains. However, their cytoplasmic domains are truncated to 30-40 amino acids. Initially the short-form leptin receptors were believed not to be involved in signal transduction, but to mediate transmembrane movement or clearance of leptin. However, recent investigations (Murakami et al., 1997; Yamashita et al., 1998) have provided evidence that the short forms of the leptin receptors $(\mathrm{Ob}-\mathrm{Ra}, \mathrm{c}$, and $\mathrm{d})$ may indeed possess functional signal transduction capabilities (ex. via JAK/mitogen-activated protein kinase (MAPK) or phosphotidyl inositol [PI]-3 kinase activation). The leptin receptor denoted as $\mathrm{Ob}-\mathrm{Re}$ is completely devoid of a cytoplasmic domain and is believed to occur in several circulating forms, possibly as soluble binding proteins (Gavrilova et al., 1997; Lollmann et al., 1997; Li et al., 1998).

Initially leptin receptors were cloned from the choroid plexus (Tartaglia et al., 1995). The significance of the choroid plexus is that it is one of the circumventricular organs within the brain where the brain is said to be 'permeable' to the exchange of substances with the peripheral blood supply. Location of leptin receptors in these neuroanatomical tissues may be a potential point of control in the regulation of the 'body-to-brain' signal. Indeed, there is evidence to support the hypothesis that the leptin transport process in the circumventricular organs is specific and saturable (Banks et al., 1996; Caro et al., 1996; Schwartz et al., 1996; Diamond et al., 1997; Corp et al., 1998; Karonen et al., 1998). In addition to the choroid plexus, leptin receptor expression has been localized in the brain to the ventromedial hypothalamus (Fig. 4), arcuate nucleus, hippocampus, thalamus, piriform cortex and anterior pituitary, and peripherally in tissues including adipocytes, liver, pancreas, fetal cartilage-bone, hair follicles, ovary, testis, uterus, heart, skeletal muscle, lung, lymph nodes, thyroid, adrenals, kidney, spleen and prostate gland (Hoggard et al., 1997; Mendiola et al., 1997; Zamorano et al., 1997). The function, if any, of leptin in many of these tissues has yet to be determined. 


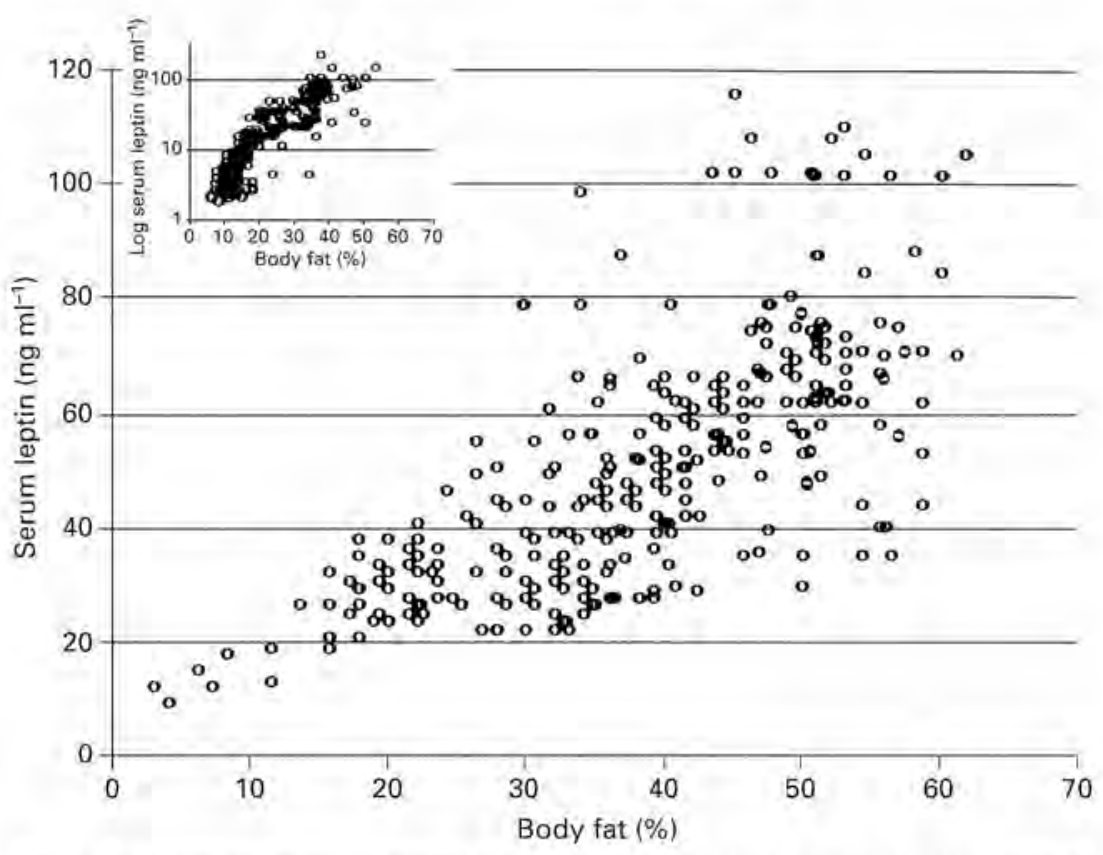

Fig. 5. Relationship between human body fat mass content and serum concentration of leptin.

\section{Role of Leptin in Nutritional Status}

All systems that perform work require fuel to function and physiological processes are not exceptions. However, unlike mechanical engines, animals possess the ability to integrate what they know about their environment and physiological status to anticipate their need for additional energy and to partition the energy among the systems in need. In order for an animal to anticipate its need for fuel and partition it appropriately, some variable or combination of variables (that is, inputs to the system) must reflect the well-being or status of each of the components of the system and the amount of fuel contained within the animal. Consequently, the fuel itself may serve as a dynamic indicator of the well-being or status of the animal by providing instantaneous yet discrete (yes versus no) assessments of status.

The fuel is important in determining whether the system functions or not, but how robust the system operates must be determined by some indicator(s) of the quality or quantity of fuel present within the animal. The issue of fuel quality implies that there are several sources of fuel which differ in energetic or satiating capabilities; and this is known to be true. For example, the brain is heavily dependent on glucose, its preferred energy substrate, but the brain can also function (within limitations) on reserves of ketones (Owen et al., 1967). Another example is that fatty acids can vary greatly in carbon-length, structural branching, and proportion of hydrogen saturation, all of which can influence the insulinogenic response within the animal. Consequently, although the quality of fuel is a mechanism by which physiological responses can be affected, it has so far received limited attention but will probably be an important area of study in the future.

Assessments of the quantity of fuel present within an animal has been long sought and has resulted in the development of a variety of electromechanical approaches, including body-condition scores, skin fold thickness, dual-energy X-ray absorptiometry (DEXA), $\mathrm{K}^{40}$ counting, and ultrasonography, all of which are focused, in essence, on estimating fat mass. The discovery of leptin and subsequent development of methods to assess it in primates and rodents has provided 

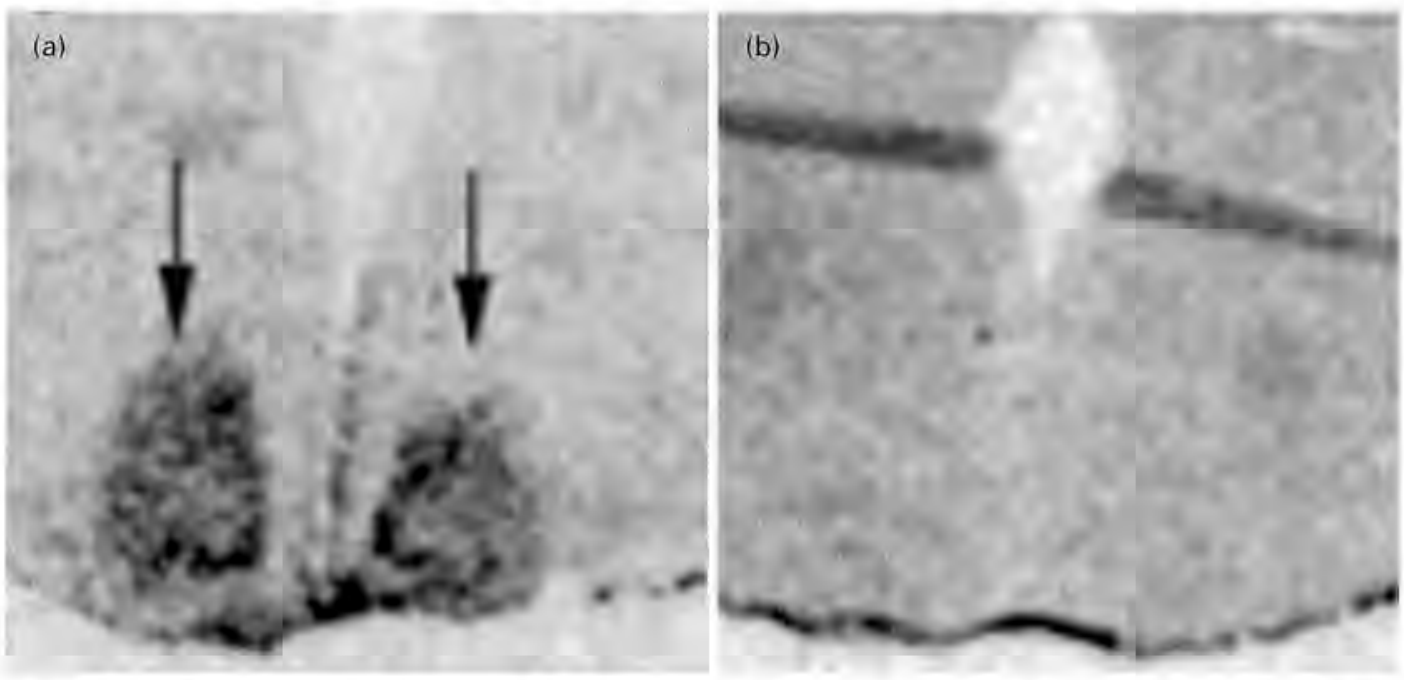

Fig. 6. NPY mRNA expression (arrows) in the ventromedial hypothalamus of feed-restricted (a) versus well-fed (b) ewes.

investigators with a relatively simple and accurate indicator of body-fat mass in these species (Fig. 5; Maffei et al., 1995; Campfield et al., 1996; Blum et al., 1997; Perry et al., 1997; Shimizu et al., 1997; Langendonk et al., 1998). Unfortunately, this relatively easily applied 'tool' has resulted in a large number of reports of replicated efforts and clinical associations between fat-mass and a variety of weakly linked conditions. The few quality studies reported so far have allowed us to focus on the relationship between fat-mass and physiological function and shape understanding of the regulatory processes involved in body 'fat and function'.

Similar tests for assessing leptin in livestock species have been developed with opportunities to: (1) monitor more accurately the 'fuel reserves' that an animal possesses in order to facilitate management of the animal and (2) potentially provide meat producers, processors, and consumers with an objective quantifier of meat quality.

As a result of years of focus on fundamental hypothesis driven research, it has been established that when animals lose body fuel reserves or fat mass, as in starvation conditions, satiety centres within the brain stimulate appetite (Hoebel, 1997; Hirschberg, 1998). Neurochemically, this is mediated, at least in part, if not predominately, by an increase in brain content of neuropeptide $Y$ (NPY; Fig. 6; Tomaszuk et al., 1996; Kalra, 1997; Yu et al., 1997; Xu et al., 1998). It is also important to note here that NPY is not being considered as the sole mediator of these processes, as there must be other collateral mechanisms to ensure the redundancy and thus preservation of this axis of communication. However, the significance of the focus on NPY is that there is evidence to support a pivotal role for NPY in regulating both nutritional status and reproductive function.

Neuropeptide $Y$ is a 37 amino acid peptide, which is known to be one of the most potent stimulators of appetite in a broad range of species. But how secretion of NPY is regulated, or more specifically which somatic signals arise outside of the brain that are capable of communicating quantity or quality of body fuel reserves to the NPY neurones are not known. The answer may be that when many of the traditional indicators of nutritional status increase, especially insulin, secretion of NPY decreases (Kalra, 1997). In addition, there are direct effects of leptin on NPY neurones, as leptin receptors have been colocalized with NPY neurones in rodents (Mercer et al., 1996) and sheep (Keisler et al., unpublished observations; see Fig. 7). Consequently, at least one axis of the 'body-to-brain' signalling pathways is direct. The functionality of this pathway has been confirmed via intracerebroventricular infusions of leptin into both well-fed and feed-restricted ewes (Henry et al., 1998; Morrison et al., 1998). The mean ( \pm one standard error) of feed-intake profiles of 


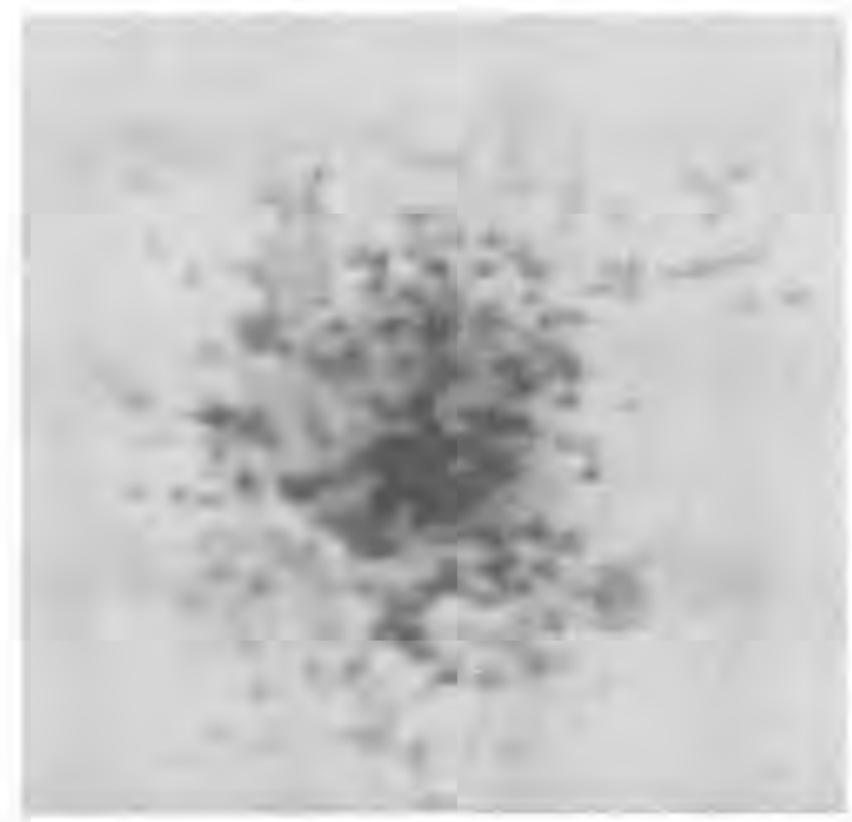

Fig. 7. $40 \times$ magnification grey scale image of a hypothalamic NPY neurone (NPY mRNA in grey) exhibiting colocalization with leptin receptor mRNA (dark silver grains).

well-fed and feed-restricted ewes receiving vehicle or recombinant ovine leptin is shown in Fig. 8 . Recombinant ovine leptin was infused in a linearly increasing dose from $0 \mu \mathrm{g} \mathrm{kg}^{-1} \mathrm{~h}^{-1}$ on day 0 to a maximum dose of $1.25 \mathrm{\mu g} \mathrm{kg}^{-1} \mathrm{~h}^{-1}$ on day 8 . Well-fed ewes receiving leptin began to decrease intake of feed on day 4 and ceased eating by day 7 of infusion. However, feed-restricted ewes receiving leptin began to limit their intake only while receiving maximum amounts of leptin. These observations may reflect the ability of an animal to balance its presumptive desire for food against its constitutive demand for food. In well-fed ewes, leptin suppressed the animals' desire for food, while fat reserves within the animal supplied its demand for food. In contrast, the feed-restricted ewes were almost devoid of body fat and, therefore, their constitutive demand for food (for survival) superseded signals (exogenous leptin) suppressing their presumptive disinterest in eating. In essence, the message that communicated the quantity (or possibly quality) of available body fuel reserves (that is, leptin) did not concur with the flagrant absence of fuel; consequently, the thin ewes continued to eat to survive.

\section{Role of Leptin in Reproductive Function}

In 1996, Barash and coworkers revealed evidence implicating a role for leptin in the reproductive axis. They reported that treatment of $o b / o b$ mice with leptin increased reproductive organ weight and serum concentrations of gonadotrophins. They thus declared leptin as a 'metabolic signal to the reproductive system'. In 1997, Chehab and coworkers substantiated the involvement of leptin in the reproductive axis by reporting that treatment of wild-type mice with leptin advanced the onset of sexual maturation by 9 days. Similarly, Carro et al. (1997) reported that administration of leptin antiserum to ovariectomized rats led to a marked decrease in secretion of LH. The validity of the observations of Chehab et al. (1997) and perhaps the observations of Carro et al. (1997) have now 

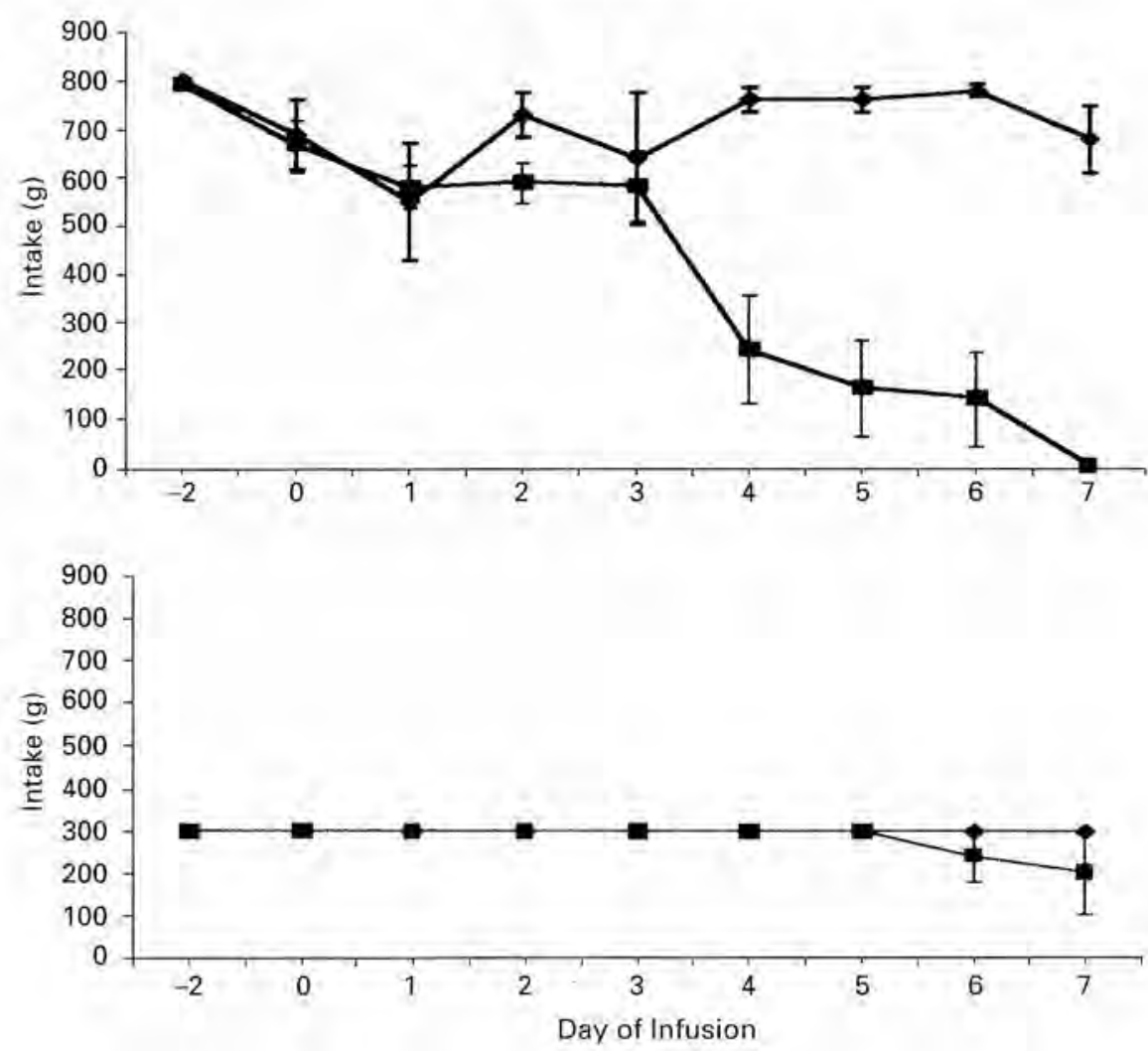

Fig. 8. Daily feed-intake of well-fed and feed-restricted ewes receiving intracerebroventricular infusions of vehicle $(-)$ or recombinant ovine leptin ( $\mathbf{m})$.

been challenged by the findings of Gruaz et al. (1998), who suggested that the action of leptin on the reproductive axis was confounded by its ability to decrease food intake and thus it is difficult to discriminate between these actions.

In addition, it is known that serum concentrations of leptin in primates and rodents: (1) are positively correlated with body weight and body mass index, (2) increase before puberty in females and to a lesser extent in males; (3) are typically three to four times greater in females than in males, and (4) are inversely related to serum concentrations of testosterone. It is also known that serum concentrations of leptin: (1) increase significantly during early pregnancy before any major changes occur in maternal body fat mass; (2) are significantly lower in newborns with intrauterine growth retardation than in newborns with normal intrauterine growth profiles and (3) are positively correlated with birth weight. In ruminants (and livestock in general), acceptable methods for assessing serum concentrations of leptin are only now being developed and information is not available so far. Furthermore, only recently has a large-scale method for the preparation of biologically active recombinant ruminant (ovine) leptin been described (Gertler et al., 1998).

Irrespective of these impediments, Henry et al. (1998) and Morrison et al. (1998) infused recombinant human and ovine leptin (respectively) into the cerebroventricles of well-fed or well-fed and feed-restricted ewes, respectively. Independently, both groups of investigators reported that well-fed ewes reduced their food intake in response to leptin. This observation is consistent with the report by Henry et al. (1998) that hypothalamic expression of NPY (a potent orexigenic protein) was 
reduced in well-fed ewes infused with leptin. In contrast, neither Henry et al. (1998) nor Morrison ef al. (1998) observed any discernible change in secretion of gonadotrophins in the well-fed ewes in response to leptin. It is possible that (1) gonadotrophin secretion in the well-fed ewes was already maximal, (2) systems governing feed intake were more responsive than systems governing reproductive responses, or (3) a further reduction in the already low hypothalamic content of NPY in the well-fed ewes was inconsequential to mechanisms governing secretion of gonadotrophins. In feed-restricted ewes (Morrison et al., 1998), cerebroventricular infusion of leptin began to reduce food intake only at maximum amounts of leptin, but again failed to alter serum concentrations of gonadotrophins. We suggest that in the feed-restricted ewes collateral mechanisms or signals (such as insulin) provide redundancy, and thus ensure the signal for food intake is maintained for the preservation of the animal. The presence of several pathways thus permits a form of checks and balances of the system. With regards to the reproductive axis, perhaps gonadotrophin secretion in the feed-restricted ewes was so inhibited that any change in NPY was not of sufficient magnitude or duration to affect an increase in gonadotrophins or collateral consequences of the feed-restricted condition prohibited an increase in gonadotrophins. Regardless of the precise mechanism of action, these observations are consistent with the hypothesis that the effects of leptin on the reproductive axis may be mediated largely, if not exclusively, by central inhibition of NPY. As stated earlier, leptin receptors have been colocalized on NPY neurones (see Fig. 7) implicating a direct body-to-brain mechanism for communicating nutritional status to the reproductive axis.

\section{Conclusion}

Although there is significant evidence implicating the role of leptin in communicating nutritional status to the reproductive axis, it is not only highly unlikely but also perilous for an animal to rely on a single mechanism to mediate these body-to-brain communications. This is not to imply that the role of leptin in this process is minimal, but rather to place the role of leptin in perspective relative to several alternative mechanisms previously examined and yet to be examined. We are only at the beginning of understanding the complexity of these 'body-to-brain' communications and their interactions and the contribution of each of the potential mediators of these processes on the local, peripheral and central tissues that constitute the animal.

\section{Contribution from the Missouri Agric, Exp. Sta. Journal Series.}

\section{References}

Banks WA, Kastin AJ, Huang WT, Jaspan JB and Maness LM (1996) Leptin enters the brain by a saturable system independent of insulin Peptides 17 305-311

Barash IA, Cheung CC, Weigle DS, Ren HP, Kabigting EB, Kuijper $\mathrm{JL}$, Clifton DK and Steiner RA (1996) Leptin is a metabolic signal to the reproductive system Endocrinology 137 3144-3147

Bjorbaek C, Uotaní S, da Silva B and Flier JS (1997) Divergent signaling capacities of the long and short isoforms of the leptin receptor Journal of Biological Chemistry 272 32686-32695

Blum WF, Englaro P, Hanitsch S, Juul A, Hertel NT, Muller J, Skakkebaek NE, Heiman ML, Birkett M, Attanasio AM, Kiess W and Rascher W (1997) Plasma leptin leyels in healthy children and adolescents: dependence on body mass index, body fat mass, gender, pubertal stage, and testosterone Journal of Clinical Endocrinology and Metabolisnt 82 2904-2910

Campfield LA, Smith FJ and Burn P (1996) The ob protein (leptin) pathway - a link between adipose tissue mass and central neural networks Hormone and Metabolic Resenrch 28 $619-632$

Caro JE, Kolaczynski JW, Nyce MR, Ohannesian JP, Opentanova I, Goldman WH, Lynn RB, Zhang PL, Sinha MK and Considine RV (1996) Decreased cerebrospinal-fluid/serum leptin ratio in obesity - a possible mechanism for leptin resistance Lancet 348 159-161

Carro Ex Pinilla L, Seoane LM, Considine RV, Aguilar E, Casanueva FF and Dieguez C (1997) Influence of endogenous leptin tone on the estrous cycle and luteinizing hormone pulsatility in female rats Neurvendocrinology 66 375-377

Chehab FE, Mounzih K, Lu RH and Lim ME (1997) Early onset of reproductive function in normal female mice treated with leptin Science $27588-90$

Coleman DL (1978) Obese and diabetes: two mutant genes causing diabetes-obesity syndromes in mice Diabetologia 14 141-148

Corp ES, Conze DB, Smith F and Campfield LA (1998) Regional localization of specific [125]leptin binding sites in rat forebrain Brain Research 789 40-47 
Devos R, Guisez Y, Van der Heyden J, White DW, Kalai M, Fountoulakis M and Plaetinck G (1997) Ligand-independent dimerization of the extracellular domain of the leptin receptor and determination of the stoichiometry of leptin binding Journal of Biological Chemistry 272 18304-18310

Diamond FB, Eichler DC, Duckett $\mathrm{G}_{+}$Jorgensen EV, Shulman D and Root AW (1997) Demonstration of a leptin binding factor in human serum Biochemical and Biophysical Research Communications 233 818-822

Gavrilova O, Barr V, Marcus-Samuels B and Reitman M (1997) Hyperleptinemia of pregnancy associated with the appearance of a circulating form of the leptin receptor Joumal of Biological Chemistry 272 30546-30551

Gertler A, Simmons J and Keisler DH (1998) Large-scale preparation of biologically active recombinant ovine obese protein (leptin) FEBS Letters 422 137-140

Girard J (1997) Is leptin the link between obesity and insulin resistance? Diabetes and Metabolism 23 (Supplement 3) $16-24$

Gruaz NM, Lalaoui M, Pierroz DD, Raposinho PD, Blum WF and Aubert ML (1998) Failure of leptin administration to advance sexual maturation in the female rat $80^{\text {th }}$ Arnual Meeting of the Endocrine Society, New Orleans Abstract P3-668

Henry B, Goding J, Alexander W, Tilbrook A, Canny B and Clarke I (1998) High doses of leptin can reduce food intake in sheep whilst not affecting the secretion of pituitary hormones $80^{\text {th }}$ Annual meeting of the Endocrine Society, New Orleans Abstract OR38-1

Hervey GR (1958) The effects of lesions in the hypothalamus in parabiotic rats fournal of Physiology 145 336-352

Hirschberg AL (1998) Hormonal regulation of appetite and food intake Annals of Medicine 30 7-20

Hoebel BG (1997) Neuroscience and appetitive behavior research - 25 years Appetite $29119-133$

Hoggard N, Hunter L, Duncan JS, Williams LM, Trayhurn P and Mercer JG (1997) Leptin and leptin receptor mRNA and protein expression in the murine fetus and placenta Proceedings of the National Academy of Sciences of the USA 94 11073-11078

Ingalis AM, Dickie MM and Snell GD (1950) Obese, a new mutation in the mouse Journal of Heredity 41 317-318

Kalra SP (1997) Appetite and body weight regulation - is it all in the brain Neuron 19 227-230

Karonen SL, Koistinen HA, Nikkinen P and Koivisto VA (1998) Is brain uptake of leptin in vivo saturable and reduced by fasting? European journal of Nuclent Medicine 25 607-612

Kennedy GC (1953) The role of depot fat in the hypothalamic control of food intake in the rat Proceedings of the Royal Society of Medicine 140 578-592

Langendonk JG, Pijl H, Toornvliet AC, Burggraaf J, Frolich M, Schoemaker RC, Doornbos J, Cohen AF and Meinders AE (1998) Circadian rhythm of plasma leptin levels in upper and lower body obese women: influence of body fat distribution and weight Ioss Journal of Clinical Endocrinology and Metabolism 83 1706-1712

Li C, Ioffe E, Fidahusein N, Connolly E and Friedman JM (1998) Absence of soluble leptin receptor in plasma from $\mathrm{dbpas} / \mathrm{dbpas}$ and other $\mathrm{db} / \mathrm{db}$ mice Journal of Biological Chemistry 273 10078-10082

Liu CL, Liu XJ, Barry G, Ling N, Maki RA and Desouza EB (1997) Expression and characterization of a putative high affinity human soluble leptin receptor Endocrinology 138 3548-3554

Lollmann B, Gruninger S, Stricker-Krongrad A and Chiesi M
(1997) Detection and quantification of the leptin receptor splice variants $\mathrm{Ob}-\mathrm{R} a, \mathrm{~b}$, and, $\mathrm{e}$ in different mouse tissues Biochemical and Biophysical Research Communications 238 $648-652$

Maffei M, Halaas J, Ravussin E, Pratley RE, Lee GH, Zhang Y, Fei H, Kim S, Lallone R, Ranganathan S, Kern PA and Friedman JM (1995) Leptin levels in human and rodert measurement of plasma leptin and ob RNA in obese and weight-reduced subjects Nature Medicine 1 1155-1161

Mendiola J, Janzen M, Cruz M and Louis CF (1997) Cloning and tissue distribution of leptin mRNA in the pig Animal Biotechnology $8227-236$

Mercer JG, Hoggard N, Williams LM, Lawrence CB, Hannah LT, Morgan PJ and Trayhurn P (1996) Coexpression of leptin receptor and preproneuropeptide $\mathrm{Y}$ mRNA in arcuate nucleus of mouse hypothalamus journal of Neiroendocrinology 8 733-735

Morrison CD, Daniel JA Holmberg B, Bolden OU and Keisler DH (1998) Effects of lateral cerebroventricular infusion of leptin on ewe lambs Journal of Animal Science 76225

Murakami T, Yamashita T, Iida M, Kuwajima M and Shima K (1997) A short form of leptin receptor performs signal transduction Biochemical and Biophysical Research Communications 231 26-29

Nakashima K, Narazaki M and Taga T (1997) Leptin receptor (obr) oligomerizes with itself but not with its closely related cytokine signal transducer gp130 FEBS Letters 403 79-82

Owen OE, Morgan AP, Kemp HG, Sullivan JM, Herrera MG and Cahill GF (1967) Brain metabolism during fasting Journal of Clinical Investigation 46 1589-1595

Perry HM, Morley JE, Horowitz M, Kaiser FE, Miller DK and Wittert G (1997) Body composition and age in africanamerican and caucasian women - relationship to plasma leptin levels Metabolism Clinical and Experimental 46 1399-1405

Schwartz MW, Peskind E, Raskind M, Boyko EJ and Porte D (1996) Cerebrospinal fluid leptin levels - relationship to plasma levels and to adiposity in humans Nature Medicine 2 $589-593$

Shimizu H, Shimomura $Y$, Hayashi R, Ohtani K, Sato N, Futawatari T and Mori M (1997) Serum leptin concentration is associated with total body fat mass, but not abdominal fat distribution International Journal of Obesity and Related Metabolic Disorders 21 536-541

Tartaglia LA, Dembski M, Weng X, Deng NH, Culpepper J, Devos R, Richards GJ, Campfield LA, Clark FT, Deeds J, Muir C, Sanker S, Moriarty A, Moore KJ, Smutko JS, Mays GG, Woolf EA, Monroe CA and Tepper RI (1995) Identification and expression cloning of a leptin receptor, ob-r Cell 83 1263-1271

Tomaszuk A, Simpson C and Williams G (1996) Neuropeptide Y, the hypothalamus and the regulation of energy homeostasis Hormone Researcl $4653-58$

Yamashita $T$, Murakami T, Otani S, Kuwajima $M$ and Shima $K$ (1998) Leptin receptor signal transduction: ObRa and $\mathrm{ObRb}$ of ta type Biochemical and Biophysical Research Communications $246752-759$

Yu WH, Kimura M, Walczewska A, Karanth S and McCann SM (1997) Role of leptin in hypothalamic-pituitary function Proceedings of the National Academy of Sciences USA 94 1023-1028

Xu B, Dube MG, Kalra PS, Farmerie WG, Kaibara A, Moldawer LL, Martin D and Kalra SP (1998) Anorectic effects of the cytokine, ciliary neurotropic factor, are mediated by 
hypothalamic neuropeptide $\gamma$ : comparison with leptin Endocrinology 139 466-473

Zamorano PL, Mahesh VB, Desevilla LM, Chorich LP, Bhat GK and Brann DW (1997) Expression and localization of the leptin receptor in endocrine and neuroendocrine tissues of the rat Neuroendocrinology $65223-228$

Zhang Y, Proenca R, Maffei M, Barone M, Leopold L and Friedman
JL (1994) Positional cloning of the mouse obese gene and its human homologue Nature 372 425-432

Zhang FM, Basinski MB, Beals JM, Briggs SL, Churgay LM, Clawson DK, Dimarchi RD, Furman TC, Hale JE, Hsiung HM, Schoner BE, Smith DP, Zhang XY, Wery JP and Schevitz RW (1997) Crystal structure of the obese protein leptin-B100 Nature 387 206-209 